\title{
Association of DNA repair genes polymorphisms with childhood acute lymphoblastic leukemia: a high-resolution melting analysis
}

\author{
Shahrzad Zehtab , Mahla Sattarzadeh Bardsiri ${ }^{1}{ }^{1,2}$, Roohollah Mirzaee Khalilabadi ${ }^{1}$, Mohsen Ehsan ${ }^{1}$ and \\ Ahmad Fatemi ${ }^{1,3^{*}}$ (1)
}

\begin{abstract}
Objective: Acute lymphoblastic leukemia (ALL) is one of the most common cancers in children for which the exact pathogenesis is not yet known. Single-nucleotide variants (SNVs) in different DNA repair genes are reported to be associated with ALL risk. This study aimed to determine the association between XRCC1 (rs1799782) and NBN (rs1805794, rs709816) SNVs and childhood ALL risk in a sample of the Iranian population. Fifty children with ALL and 50 age- and sex-matched healthy children were included in this case-control study. Genotyping of the mentioned SNVs was done by high-resolution melting (HRM) analysis.

Results: The prevalence of all three SNVs in XRCC1 and NBN genes did not differ between the patient and control groups, and these polymorphisms were not associated with childhood ALL risk $(P>0.05)$. HRM was a practical method for the detection of SNVs in XRCC1 and NBN genes. We found no significant association between XRCC1 (rs1799782) and NBN (rs1805794, rs709816) SNVs and childhood ALL risk.
\end{abstract}

Keywords: Childhood acute lymphoblastic Leukemia, XRCC1, NBN, Single nucleotide variants, High-resolution melting analysis

\section{Introduction}

Globally, acute lymphoblastic leukemia (ALL) is the first most common form of childhood cancer and constitutes about $25-30 \%$ of all malignancies in those aged $2-5$ years [1]. ALL is a heterogeneous disorder that arises from a malignant transformation and proliferation of lymphoid progenitors in bone marrow, peripheral blood, lymph nodes, and thymus [2]. It has been hypothesized that the initiation of ALL occurs in early infancy [3]. Overall survival (OS) in children is estimated close to $90 \%$ but

*Correspondence: ahmad.fatemi2@gmail.com

${ }^{3}$ Cellular and Molecular Research Center, Gerash University of Medical Sciences, Gerash, Iran

Full list of author information is available at the end of the article patients with relapsed/refractory ALL present a therapeutic challenge $[1,4]$. ALL progresses rapidly and it is suggested that a combination of genetic susceptibility and environmental factors contribute to disease development. However, the exact roles of both genetic and environmental factors as risk factors for ALL remain poorly understood and they require further study [5-7]. One of the major guilty of ALL pathogenesis is DNA damage. Humans are routinely adventured to endogenous and exogenous damaging factors [8]. Environmental exposures such as ultraviolet light, ionizing radiation, and chemical agents cause exogenous DNA damage. In addition, DNA may be damaged by endogenous factors such as oxidative stress, alkylation, hydrolysis (deamination, depurination, and depyrimidination), and mismatch of 
DNA bases $[8,9]$. To overcome these lesions and maintain genome integrity, cells possess several DNA repair systems that remove many DNA damages [10]. These mechanisms are double-strand break repair, direct repair (MGMT), base excision repair (BER), nucleotide excision repair, and mismatch repair pathway [11]. In several studies have been reported that single nucleotide variants (SNVs) in genes encoding DNA repair proteins could be associated with ALL risk [12].

The BER pathway is primarily responsible for removing DNA lesions such as oxidized bases, alkylated bases, and abasic (AP) sites [13]. This pathway is a multistep process that requires the activation of several proteins and the deficiencies and changes in the efficiency of these proteins have been associated with diminished DNA repair capacity and individual susceptibility to cancer [14]. The $\mathrm{x}$-ray repair cross-complementing group 1 (XRCC1) is one of the BER components. XRCC1 gene is located on the long arm of chromosome 19 (19q13.2) and consists of 17 exons encoding a 633 amino acid protein which plays a crucial role as a scaffold and multifunctional protein in BER [9]. XRCC1 has a domain for biologically significant interactions with other BER proteins, including poly (ADP-ribose) polymerase 1 (PARP-1), the gap-filling DNA polymerase $\beta$ (POL $\beta$ ), the DNA 30 - phosphatase (PNKP), and DNA ligase 3a (LIG3a) [15]. SNVs are DNA base variants with a frequency of more than $1 \%$ in the human population [16]. SNV in the coding sequences of $X R C C 1$ was shown to potentially associate with modulated DNA repair capacity, making it a risk factor to occurrence of various cancers, especially hematopoietic diseases [17]. Three common SNVs have been identified in the XRCC1 gene in humans (Arg194Trp, Arg280His, and Arg399Gln) $[18,19]$. One of them is rs1799782 (at position 26304 on exon 6, base G to A, amino acid Arg to Trp) in the codon 194 which may alter XRCC1 function [20].

Another DNA repair protein is Nibrin, encoded by the $N B N$ gene located on chromosome $8 \mathrm{q} 21$. This protein is associated with both homologous recombination (HR) and non-homologous end-joining (NHEJ) DNA doublestrand breaks (DSBs) repair pathways [21-23]. The protein is a member of the NBS1/hMre11/RAD50 (N/M/R) complex that plays a key role in DNA DSBs repair [2426]. Genetic variants in $N B N$ may modulate the function of the protein and so the DNA repair capacity. In the past decade, 675 SNVs were reported for the NBN gene to be associated with multiple cancers [27]. Two common NBN SNVs, based on minor allele frequency of $>5 \%$, are rs1805794 in the codon 185 (exon 8, base C to G, amino acid Glu to Gln) and rs709816 in the codon 399 (exon 8, base A to G, Asp to Asp) which may alter NBN function [28].

According to this fact that the prevalence of genetic polymorphisms is racially dependent, so evaluation of these variations in different populations provides valuable information about leukemia susceptibility and disease prognosis. To enhance our knowledge about these variations, we designed a case-control study to investigate the association between XRCC1 (rs1799782) and NBN (rs1805794, rs709816) genes polymorphisms and ALL risk in the Iranian population (Kerman province).

\section{Main Text \\ Methods \\ Participants}

This case-control study included 50 children diagnosed with ALL (based on current 2008 World Health Organization criteria) and 50 healthy children with no previous history of malignancy. All subjects in both case and control groups were matched for age and sex.

\section{DNA extraction}

Genomic DNA was extracted from 1.5 mL EDTA-anticoagulated whole blood samples using the modified saltingout method [29]. Extracted DNA samples were stored at $-20{ }^{\circ} \mathrm{C}$ until genotyping.

\section{SNV genotyping by high-resolution melting (HRM) analysis}

HRM analysis was performed using the Rotor-Gene ${ }^{\circledR} \mathrm{Q}$ instrument (QIAGEN's real-time PCR cycler). According to the manufacturer's protocol of $5 \times \mathrm{HOT}$ FIREPol $^{\circledR}$ EvaGreen ${ }^{\circledR}$ HRM Mix (Solis BioDyne, Estonia), Components of an HRM reaction included: $1 \times \mathrm{HRM}$ Master Mix, $100 \mathrm{nM}$ forward primer $(10 \mathrm{pmol} / \mu \mathrm{L}), 100 \mathrm{nM}$ reverse primer $(10 \mathrm{pmol} / \mu \mathrm{L}), 50 \mathrm{ng} / \mu \mathrm{L}$ DNA template and $\mathrm{H} 2 \mathrm{O}$ PCR grade. The final volume of the reaction mixture was $20 \mu \mathrm{L}$. Then, DNA was amplified under these cycling conditions: Initial activation at $95{ }^{\circ} \mathrm{C}$ for $12 \mathrm{~min}$, followed by 40 cycles of amplification consisting of denaturation at $95^{\circ} \mathrm{C}$ for $15 \mathrm{~s}$, annealing at $67^{\circ} \mathrm{C}$ for $20 \mathrm{~s}$, and extension at $72{ }^{\circ} \mathrm{C}$ for $20 \mathrm{~s}$. Finally, an HRM step was performed with an increase in temperature from 65 to $90^{\circ} \mathrm{C}$ at a ramp rate of $0.1{ }^{\circ} \mathrm{C}$ per second. All data were analyzed using Rotor-Gene Q Series Software. Primer sequences and general information for each SNV are shown in Additional file 1: Table S1.

\section{DNA sequencing}

Because of obtaining different groups of melt curves and to ensure the accuracy of genotyping by HRM assay, three samples from each group were sent to BIONEER Corporation (South Korea) for direct DNA sequencing. 


\section{Statistical analysis}

Pearson Chi-square test was used to compare the frequency of genotypes and alleles between case and control groups. To investigate the expected frequency of control genotypes, Hardy-Weinberg equilibrium (HWE) was applied. To determine the association of each genotype and risk of ALL, odds ratios (ORs) and 95\% confidence intervals (CIs) were calculated using multivariate logistic regression. Statistical analyses were carried out with SPSS software version 23.0. A $P$ value less than 0.05 was considered statistically significant.

\section{Results}

\section{Baseline characteristics of patients and controls}

Our study included 50 children with ALL (age $5.5 \pm 5.4$ years) and 50 healthy children (age $6.2 \pm 2.8$ years). Demographic and hematologic characteristics of participants are presented in Table 1. All subjects in both case and control groups were matched for age $(P=0.41)$ and sex $(P=0.83)$. Hematologic parameters including red blood cell count, hemoglobin, hematocrit and platelet count were significantly associated with childhood ALL $(\mathrm{P}<0.0001)$.

\section{HRM and sequencing results}

We used HRM assay to detect XRCC1 (rs1799782 G > A) and $N B N($ rs1805794 $\mathrm{C}>\mathrm{G}$, rs709816 $\mathrm{A}>\mathrm{G})$ gene polymorphisms. After analyzing, it was found that the melting curves show different patterns, so several samples from each group were selected for sequencing. Supplementary figures (Additional file 2: Fig. S1, Additional file 3: Fig. S2, Additional file 4: Fig. S3) show the results of sequencing for each SNV as well as the genotyping results obtained by the HRM technique presented in three models (melting curve, normalized graph, and difference graph).

\section{Genotype and allele frequency of XRCC1 and NBN genes polymorphisms and the association with childhood ALL}

The genotype distributions for SNV rs1799782 (XRCC1 $\mathrm{A}>\mathrm{G}$ ) and SNV rs709816 (NBN G>A) were in HardyWeinberg Equilibrium $(P>0.05)$ in both patients and controls, but for SNV rs1805794 (NBN C > G) were not $(P<0.001)$ in both groups (Table 2 caption). The frequency of genotypes and alleles in the studied groups is presented in Table 2. Our data revealed no significant differences in genotype and allelic distribution of all three SNVs between the patient and control groups $(P>0.05)$. Accordingly, we could not find any statistically significant

Table 1 Demographic and hematologic parameters

\begin{tabular}{|c|c|c|c|c|c|c|}
\hline Parameters & & & Male & & Female & P-value \\
\hline \multicolumn{7}{|l|}{ Gender } \\
\hline Control & & & $16(32.0 \%)$ & & $34(68.8 \%)$ & 0.832 \\
\hline \multirow[t]{2}{*}{ Patient } & & & $17(34.0 \%)$ & & $33(66.0 \%)$ & \\
\hline & $\mathrm{N}$ & Mean \pm SD & & Median & IQR & P-value \\
\hline \multicolumn{7}{|l|}{ Age } \\
\hline Control & 50 & $6.2 \pm 2.8$ & & 6 & 5.25 & 0.418 \\
\hline Patient & 50 & $5.5 \pm 5.4$ & & 5 & 4.5 & \\
\hline \multicolumn{7}{|c|}{ Red blood cells count $\times 10^{12} / \mathrm{L}$} \\
\hline Control & 50 & $4.62 \pm 0.55$ & & 4.67 & 0.79 & $<0.0001$ \\
\hline Patient & 50 & $3.22 \pm 1.07$ & & 3.47 & 1.55 & \\
\hline \multicolumn{7}{|c|}{ Hemoglobin (g/dL) } \\
\hline Control & 50 & $13.17 \pm 0.88$ & & 13.2 & 1.33 & $<0.0001$ \\
\hline Patient & 50 & $8.48 \pm 2.69$ & & 9.05 & 4.02 & \\
\hline \multicolumn{7}{|l|}{ Hematocrit\% } \\
\hline Control & 50 & $38.29 \pm 2.70$ & & 38.7 & 4.65 & $<0.0001$ \\
\hline Patient & 50 & $31.21 \pm 7.46$ & & 31.79 & 12.35 & \\
\hline \multicolumn{7}{|c|}{ White blood cells count $\times 10^{9} / \mathrm{L}$} \\
\hline Control & 50 & $7.69 \pm 1.18$ & & 7.77 & 1.99 & 0.145 \\
\hline Patient & 50 & $19.34 \pm 30.30$ & & 6.3 & 14.58 & \\
\hline \multicolumn{7}{|c|}{ Platelet count $\times 10^{9} / \mathrm{L}$} \\
\hline Control & 50 & $277.50 \pm 277.68$ & & 217 & 108 & $<0.0001$ \\
\hline Patient & 50 & $128.54 \pm 157.54$ & & 54.5 & 198.25 & \\
\hline
\end{tabular}


Table 2 Genotype and allele frequency of XRCC1 and NBN genes polymorphisms and the association with childhood ALL

\begin{tabular}{|c|c|c|c|c|c|c|c|c|}
\hline & \multicolumn{3}{|l|}{ Group } & & \multirow[t]{2}{*}{ P-Value } & \multirow[t]{2}{*}{ OR } & \multicolumn{2}{|c|}{$95 \% \mathrm{Cl}$ for OR } \\
\hline & Control & & Patient & & & & Lower & Upper \\
\hline \multicolumn{9}{|l|}{ XRCC1 rs1799782 G>A } \\
\hline \multicolumn{9}{|l|}{ Genotype } \\
\hline GG & $45(48.9 \%)$ & & $47(51.1 \%)$ & & - & 1 & - & - \\
\hline GA & $0(0.0 \%)$ & & $0(0.0 \%)$ & & - & - & - & - \\
\hline AA & $5(62.5 \%)$ & & $3(37.5 \%)$ & & 0.465 & 0.574 & 0.130 & 2.545 \\
\hline \multicolumn{9}{|l|}{ Dominant model } \\
\hline $\mathrm{GA}+\mathrm{AA}$ & $5(62.5 \%$ & & $3(37.5 \%)$ & & 0.465 & 0.574 & 0.130 & 2.545 \\
\hline \multicolumn{9}{|l|}{ Recessive model } \\
\hline $\mathrm{GG}+\mathrm{GA}$ & $45(48.9 \%)$ & & $47(51.1 \%)$ & & 0.465 & 1.74 & 0.393 & 7.713 \\
\hline \multicolumn{9}{|l|}{ Allele } \\
\hline G & $90(48.9 \%)$ & & $94(51.1 \%)$ & & - & 1 & - & - \\
\hline A & $10(62.5 \%)$ & & $6(37.5 \%)$ & & 0.297 & 0.574 & 0.201 & 1.646 \\
\hline \multicolumn{9}{|l|}{ NBN rs709816 A > G } \\
\hline \multicolumn{9}{|l|}{ Genotype } \\
\hline AA & $21(51.2 \%)$ & & $20(48.8)$ & & - & 1 & - & - \\
\hline$A G$ & $24(52.2 \%)$ & & $22(47.8 \%)$ & & 0.963 & 0.962 & 0.415 & 2.235 \\
\hline GG & $5(38.5 \%)$ & & $8(61.5 \%)$ & & 0.420 & 1.68 & 0.470 & 6.007 \\
\hline \multicolumn{9}{|l|}{ Dominant model } \\
\hline$A G+G G$ & $29(49.2 \%)$ & & $30(50.8 \%)$ & & 0.839 & 1.086 & 0.489 & 2.214 \\
\hline \multicolumn{9}{|l|}{ Recessive model } \\
\hline$A A+A G$ & $45(51.7 \%)$ & & $42(48.3 \%)$ & & 0.376 & 0.583 & 0.177 & 1.925 \\
\hline \multicolumn{9}{|l|}{ Allele } \\
\hline A & $66(51.5 \%)$ & & $62(48.4 \%)$ & & - & 1 & - & - \\
\hline G & $34(47.2 \%)$ & & $38(52.7 \%)$ & & 0.556 & 1.190 & 0.667 & 2.121 \\
\hline \multicolumn{9}{|l|}{ NBN rs 1805794 C> G } \\
\hline \multicolumn{9}{|l|}{ Genotype } \\
\hline $\mathrm{CC}$ & $28(53.8 \%)$ & & $24(46.2 \%)$ & & - & 1 & - & - \\
\hline$C G$ & $22(45.8 \%)$ & & $26(54.2 \%)$ & & 0.42 & 1.378 & 0.628 & 3.029 \\
\hline GG & $0(0.0 \%)$ & & $0(0.0 \%)$ & & - & - & - & - \\
\hline \multicolumn{9}{|l|}{ Dominant model } \\
\hline $\mathrm{CG}+\mathrm{GG}$ & $22(45.8 \%)$ & & $26(54.2 \%)$ & & 0.423 & 1.378 & 0.628 & 3.029 \\
\hline \multicolumn{9}{|l|}{ Recessive model } \\
\hline $\mathrm{CC}+\mathrm{CG}$ & $50(50.0 \%)$ & & $50(50.0 \%)$ & & - & - & - & - \\
\hline \multicolumn{9}{|l|}{ Allele } \\
\hline C & $78(51.3 \%)$ & & $74(48.6)$ & & - & 1 & - & - \\
\hline G & $22(45.8 \%)$ & & $26(54.1 \%)$ & & 0.508 & 1.246 & 0.650 & 2.388 \\
\hline \multicolumn{9}{|l|}{ NBN SNVs interaction } \\
\hline & \multirow{2}{*}{\multicolumn{2}{|c|}{ B }} & \multirow{2}{*}{\multicolumn{2}{|c|}{ P-Value }} & & OR & \multicolumn{2}{|l|}{$95 \% \mathrm{Cl}$ for OR } \\
\hline & & & & & & & Lower & Upper \\
\hline rs709816 by rs 1805794 & & 1.119 & & 0.336 & & 3.062 & 0.313 & 29.948 \\
\hline
\end{tabular}

Hardy-Weinberg Equilibrium (HWE) results for $X R C C 1$ and NBN genes polymorphisms: rs1799782 (XRCC1 G $>A)$, Control Group (X2 =0.13, $P=0.7)$, Case Group $(X 2=0.04, P=0.8)$; rs1805794 (NBN C > G): Control Group ( $X 2=3.97, P=0.04)$, Case Group $(X 2=6.17, P=0.01)$; rs709816 (NBN A>G): Control Group ( $X 2=0.24$, $\mathrm{P}=0.62)$, Case Group $(\mathrm{X} 2=0.21, \mathrm{P}=0.63)$

association between these SNVs, rs1799782 (XRCC1 $\mathrm{G}>\mathrm{A} ; \mathrm{OR}=0.57,95 \% \mathrm{CI} 0.13-2.54, P=0.46$, AA vs. GG; $\mathrm{OR}=0.57,95 \%$ CI 0.13-2.54, $P=0.46$, Dominant model, $\mathrm{GA}+\mathrm{AA}$ vs. GG; $\mathrm{OR}=1.74,95 \%$ CI $0.39-7.17, P=0.46$,
Recessive model, GG + GA vs. AA; OR $=0.57,95 \%$ CI $0.20-1.64, P=0.29$, A allele vs. G allele), rs1805794 (NBN $\mathrm{C}>\mathrm{G}$; $\mathrm{OR}=1.37,95 \% \mathrm{CI} 0.62-3.02, P=0.42$, CG vs. $\mathrm{CC}$; $\mathrm{OR}=1.37,95 \%$ CI $0.62-3.02, P=0.42$, Dominant model, 
$\mathrm{CG}+\mathrm{GG}$ vs. $\mathrm{CC} ; \mathrm{OR}=1.24,95 \% \mathrm{CI} 0.65-2.38, P=0.5$, $\mathrm{G}$ allele vs $\mathrm{C}$ allele) and rs709816 (NBN A > G; OR $=0.96$, 95\% CI $0.41-2.23, P=0.96$, AG vs. AA; OR $=1.68,95 \%$ CI $0.47-6.00, P=0.42, \mathrm{GG}$ vs. $\mathrm{AA} ; \mathrm{OR}=1.08,95 \% \mathrm{CI}$ 0.48-2.21, $P=0.83$, Dominant model, AG+GG vs. AA; $\mathrm{OR}=0.58,95 \%$ CI $0.17-1.92, P=0.37$, Recessive model, $\mathrm{AA}+\mathrm{AG}$ vs. GG; OR=1.19, 95\% CI 0.66-2.12, $P=0.55$, $G$ allele vs. A allele), and the risk of childhood ALL.

In addition, the interaction analysis of the NBN SNVs (rs709816 by rs1805794) did not showed any statistically significant association with childhood ALL (OR =3.06, 95\% CI $0.31-29.94, P=0.33)$. Multivariate regression analysis results, expressing the impact of each variable independently, are presented in Table 3. Accordingly, the studied SNVs were not associated with childhood ALL $(\mathrm{P}>0.05)$.

\section{Discussion}

ALL is a complex disease influenced by both genetic and environmental factors [30]. One of the important factors in the development of this leukemia is genetic variations including SNVs as the most common type of variations [30]. In the present study, we investigated the influence of polymorphisms within XRCC1 (rs1799782 G>A) and NBN (rs1805794 $\mathrm{C}>\mathrm{G}$, rs709816 A $>\mathrm{G}$ ) genes on susceptibility to childhood ALL in a sample of the Iranian population by HRM analysis as a powerful, cost-effective and practicable method [31, 32] for detecting SNVs and discriminating the wild type and mutant genotypes with melting temperature shifts more than $0.4{ }^{\circ} \mathrm{C}$ [33]. rs1799782 G>A is located in the coding sequence of XRCC1 and associated with modulated DNA repair capacity [34]. According to the present results, there was no significant association

Table 3 Multivariate regression analysis results

\begin{tabular}{|c|c|c|c|c|c|}
\hline \multirow[t]{2}{*}{ Variables } & \multirow[t]{2}{*}{ B } & \multirow[t]{2}{*}{ P-Value } & \multirow[t]{2}{*}{ Adjusted OR } & \multicolumn{2}{|c|}{$95 \% \mathrm{Cl}$ for OR } \\
\hline & & & & Lower & Upper \\
\hline rs1799782 (AA) & 3.894 & 0.143 & 49.106 & 0.267 & 9047.383 \\
\hline $\begin{array}{l}\text { rs1799782 (A } \\
\text { allele) }\end{array}$ & -0.585 & 0.278 & 0.557 & 0.194 & 1.603 \\
\hline rs1805794 (CG) & 0.325 & 0.863 & 1.384 & 0.034 & 55.566 \\
\hline $\begin{array}{l}\text { rs1805794 (G } \\
\text { allele) }\end{array}$ & 0.328 & 0.353 & 1.388 & 0.695 & 2.773 \\
\hline rs709816 (AG) & 0.158 & 0.932 & 1.171 & 0.031 & 44.399 \\
\hline rs709816 (GG) & -0.821 & 0.765 & 0.44 & 0.002 & 95.909 \\
\hline $\begin{array}{l}\text { rs } 709816 \text { (G } \\
\text { allele) }\end{array}$ & 0.285 & 0.364 & 1.33 & 0.718 & 2.462 \\
\hline $\begin{array}{l}\text { Red blood cell } \\
\text { count }\end{array}$ & 0.226 & 0.866 & 1.254 & 0.091 & 17.271 \\
\hline Hemoglobin & -3.159 & 0.012 & 0.042 & 0.004 & 0.497 \\
\hline Hematocrit & -0.485 & 0.033 & 0.616 & 0.395 & 0.961 \\
\hline Platelet count & -0.002 & 0.705 & 0.998 & 0.987 & 1.009 \\
\hline
\end{tabular}

between this SNV and ALL risk in our population. Similar to our finding, Joseph et al. showed that this polymorphism did not affect the susceptibility to ALL in Indian children [35]. Besides, no significant differences were observed among Turkish patients with childhood ALL and the controls concerning this polymorphism. In this study, however, Batar et al. reported that the combined XRCC1 AG/AA variant genotypes were associated with increased risk for ALL in females $(\mathrm{OR}=5.47$; 95\% CI 1.49-20.10; $\mathrm{p}=0.008$ ) [34]. A meta-analysis of 38 case-control studies indicated that XRCC1 Arg194Trp may be a biomarker of cancer susceptibility [36]. Other SNVs examined in the present study were rs1805794 $\mathrm{C}>\mathrm{G}$ and rs709816 $\mathrm{A}>\mathrm{G}$, localized to the coding sequences of the NBN gene, which may modulate the protein function and so the DNA DSB repair capacity [37]. In our study, no significant association was observed between the NBN polymorphisms and susceptibility to childhood ALL. Similar to our results, Mosor et al. genotyped six polymorphisms of the $N B N$ gene in the Poland population and suggested that one specific variant of the gene may be associated with childhood acute leukemia but no significant association was detected for the remaining five NBN polymorphisms including rs1805794 and rs709816 [38]. Consistently, in the other study on 460 pediatric ALL cases and 552 healthy controls in the European population (Germany), Smolkova et al. also did not show any association between the NBN polymorphisms and ALL risk [39]. These results show that our population, at least in part, is closely related to the European population. In contrast, in the study of the Chinese population conducted on 175 patients with ALL and 350 controls, Jiang et al. observed a significant difference in frequencies of rs1805794 C/G between cases and controls $(P<0.0001)$ and reported for the first time that $\mathrm{CC}$ genotype carriers were associated with a 3.4-fold elevated risk of ALL, compared with the non-carries [27]. Also, a meta-analysis of rs1805794 including 3065 subjects revealed the association of CC genotype with approximately 1.70-fold increased risk of acute leukemia. In contrast, there was no association between rs709816 and risk of acute leukemia in the metaanalysis of including 1,485 samples [37].

In conclusion, we cannot recognize any association between the XRCC1 and NBN polymorphisms and susceptibility to childhood ALL in a sample of the Iranian population.

\section{Limitations}

- The discrepancy of our results with other studies may be due to the small sample size and so we suggest that similar studies be conducted on the larger sample size and different populations. 
- The three SNVs in DNA repair genes may not give as comprehensive a view of genetic variation as genomic sequencing does.

- These SNVs may probably exert their effects through complex gene-gene and/or gene-environment interactions. Such interactions were not investigated in this study.

\section{Abbreviations}

ALL: Acute lymphoblastic leukemia; BER: Base excision repair; Cl: Confidence intervals; DSBs: DNA double-strand breaks; HRM: High-resolution melting; HR: Homologous recombination; LIG3a: Ligase 3a; NHEJ: Non-homologous end-joining; OS: Overall survival; ORs: Odds ratios; PARP-1: Poly (ADP-ribose) polymerase 1;POL $\beta$ : Polymerase $\beta ;$ XRCC1: $X$-ray repair cross-complementing group $1 ;$ SNVs: Single nucleotide variants.

\section{Supplementary Information}

The online version contains supplementary material available at https://doi. org/10.1186/s13104-022-05918-3.

Additional file 1: Table S1. Primer sequences for detection of XRCC1 and NBN gene polymorphisms using the HRM method.

Additional file 2: Fig. S1. Genotyping of XRCC1 (rs1799782) gene polymorphism by HRM analysis. (A) rs $1799782 \mathrm{G}>$ A Normalized graph; (B) rs1799782 G>A Melting curve; (C) rs1799782 G>A Difference graph; (D) rs1799782 G>A sequencing results.

Additional file 3: Fig. S2. Genotyping of NBN (rs1805794) gene polymorphism by HRM analysis. (A) rs1805794 C> G Normalized graph; (B) rs1805794 C> G Melting curve; (C) rs1805794 C> G Difference graph; (D) rs1805794 C > G sequencing results.

Additional file 4: Fig. S3. Genotyping of NBN (rs709816) gene polymorphism by HRM analysis. (A) rs709816 A>G Normalized graph; (B) rs709816 A>G Melting curve; (C) rs709816 A>G Difference graph; (D) rs709816 A>G sequencing results.

\section{Acknowledgements}

We would like to be grateful to Kerman University of Medical Sciences for supporting this study by Grant No. 96000989.

\section{Authors' contributions}

SZ: investigation, formal analysis, writing —original draft preparation, visualization. MSB: investigation. RMK: methodology. ME: resources. AF: conceptualization, supervision, methodology, validation, writing - reviewing and editing. All authors read and approved the final manuscript.

\section{Funding}

This study was supported by Grant No. 96000989 from the Kerman University of Medical Sciences.

\section{Availability of data and materials}

The datasets used and/or analysed during the current study are not publicly available due to the possibility of compromising the privacy of individuals. According to the written approval forms accepted by the Ethics Committee of the Kerman University of Medical Sciences (KMU), the data will only be accessible to researchers within the project. The data would be available from the corresponding author on reasonable request.

\section{Declarations}

\section{Ethics approval and consent to participate}

The project was approved by the ethical committee of Kerman University of Medical Sciences. The ethical approval code: IR.KMU.REC.1397.075. Written informed consent was obtained from parents/legal guardians of all participants. All methods were performed by the relevant guidelines and regulations.

\section{Consent for publication}

Not applicable.

\section{Competing interests}

The authors declare that they have no conflict of interest.

\section{Author details}

${ }^{1}$ Department of Hematology and Medical Laboratory Sciences, Faculty of Allied Medicine, Kerman University of Medical Sciences, Kerman, Iran. ${ }^{2}$ Cell Therapy and Regenerative Medicine Comprehensive Center, Kerman University of Medical Sciences, Kerman, Iran. ${ }^{3}$ Cellular and Molecular Research Center, Gerash University of Medical Sciences, Gerash, Iran.

Received: 30 September 2021 Accepted: 25 January 2022

Published online: 14 February 2022

\section{References}

1. Abo-Bakr A, Mossallam G, El Azhary N, et al. Impact of CYP1A1, GSTP1 and XRCC1 genes polymorphisms on toxicity and response to chemotherapy in childhood acute lymphoblastic leukemia. J Egypt Natl Canc Inst. 2017:29:127-33.

2. Lymphoid leukemia-an overview / ScienceDirect topics. https://www. sciencedirect.com/topics/medicine-and-dentistry/lymphoid-leukemia. Accessed 1 May 2020.

3. Al-Absi B, Razif MFM, Noor SM, et al. Contributions of IKZF1 DDC, CDKN2A, CEBPE, and LMO1 gene polymorphisms to acute lymphoblastic leukemia in a yemeni population. Genet Test Mol Biomarkers. 2017;21:592-9.

4. Jung $\mathrm{SH}$, Lee $\mathrm{SE}$, Lee $\mathrm{M}$, et al. Circulating microRNA expressions can predict the outcome of lenalidomide plus low-dose dexamethasone treatment in patients with refractory/relapsed multiple myeloma. Haematologica. 2017;102:e456.

5. Belson M, Kingsley B, Holmes A. Risk factors for acute leukemia in children: a review. Environ Health Perspect. 2007;115:138-45.

6. Maternal pesticide exposure and childhood leukemia: epidemiology. https://journals.lww.com/epidem/Fulltext/2000/03000/Maternal_Pesti cide_Exposure_and_Childhood_Leukemia.27.aspx. Accessed 24 Feb 2020.

7. Chokkalingam AP, Bartley K, Wiemels JL, et al. Haplotypes of DNA repair and cell cycle control genes, $X$-ray exposure, and risk of childhood acute lymphoblastic leukemia. Cancer Causes Control. 2011;22:1721-30.

8. Poomphakwaen K, Promthet S, Suwanrungruang K, et al. XRCC1 gene polymorphism, diet and risk of colorectal cancer in Thailand. Asian Pacific J Cancer Prev. 2014;15:7479-86.

9. Norjmaa B, Tulgaa K, Saitoh T. Base excision repair pathway and polymorphisms of XRCC1 gene. J Mol Pathol Epidemiol. 2016;1:1-4.

10. Bolufer P, Barragan E, Collado M, et al. Influence of genetic polymorphisms on the risk of developing leukemia and on disease progression. Leuk Res. 2006;30:1471-91.

11. Li Y, Bai O, Cui J, et al. Genetic polymorphisms in the DNA repair gene, XRCC1 associate with non-Hodgkin lymphoma susceptibility: a systematic review and meta-analysis. Eur J Med Genet. 2016;59:91-103.

12. Yang X, Ma L, Zhao X, et al. A meta-analysis study on XRCC1 Arg399Gln polymorphism and hematological malignancies. Int J Clin Exp Med. 2016;9:19244-55. 
13. Hegde ML, Izumi T, Mitra S. Oxidized base damage and single-strand break repair in mammalian genomes: role of disordered regions and posttranslational modifications in early enzymes. Prog Mol Biol Transl Sci. 2012;110:123-53.

14. Khan NP, Pandith AA, Yousuf A, et al. The XRCC1 Arg399Gln gene polymorphism and risk of colorectal cancer: a study in Kashmir. Asian Pac J Cancer Prev. 2013;14:6779-82.

15. Caldecott KW, Aoufouchi S, Johnson P, et al. XRCC1 polypeptide interacts with DNA polymerase $\beta$ and possibly poly (ADP-ribose) polymerase, and DNA ligase III is a novel molecular "nick-sensor" in vitro. Nucleic Acids Res. 1996;24:4387-94.

16. Ochiai $\mathrm{H}$. Single-base pair genome editing in human cells by using sitespecific endonucleases. Int J Mol Sci. 2015;16:21128-37.

17. Brisson GD, Alves LR, Pombo-de-Oliveira MS. Genetic susceptibility in childhood acute leukemias: a systematic review. Ecancermedicalscience. 2015. https://doi.org/10.3332/ecancer.2015.539.

18. Mateuca RA, Roelants M, larmarcovai G, et al. hOGG1326, XRCC1399 and XRCC3241 polymorphisms influence micronucleus frequencies in human lymphocytes in vivo. Mutagenesis. 2008;23:35-41.

19. Weng H, Weng Z, Lu Y, et al. Effects of cigarette smoking, XRCC1 genetic polymorphisms, and age on basal DNA damage in human blood mononuclear cells. Mutat Res Genet Toxicol Environ Mutagen. 2009;679:59-64.

20. Wang R, Hu X, Zhou Y, et al. XRCC1 Arg399GIn and Arg194Trp polymorphisms in childhood acute lymphoblastic leukemia risk: a meta-analysis. Leuk Lymphoma. 2013;54:153-9.

21. Carney JP, Maser RS, Olivares H, et al. The hMre11/hRad50 protein complex and Nijmegen breakage syndrome: Linkage of double-strand break repair to the cellular DNA damage response. Cell. 1998;93:477-86.

22. Varon R, Vissinga C, Platzer M, et al. Nibrin, a novel DNA double-strand break repair protein, is mutated in Nijmegen breakage syndrome. Cell. 1998;93:467-76.

23. Williams RS, Dodson GE, Limbo O, et al. Nbs1 flexibly tethers Ctp1 and Mre11-Rad50 to coordinate DNA double-strand break processing and repair. Cell. 2009;139:87-99.

24. Schiller CB, Lammens K, Guerini I, et al. Structure of Mre11-Nbs1 complex yields insights into ataxia-telangiectasia-like disease mutations and DNA damage signaling. Nat Struct Mol Biol. 2012;19:693.

25. D'amours D, Jackson SP. The Mre11 complex: at the crossroads of DNA repair and checkpoint signaling. Nat Rev Mol Cell Biol. 2002;3:317-27.

26. Kobayashi J, Antoccia A, Tauchi H, et al. NBS1 and its functional role in the DNA damage response. DNA Repair. 2004;3:855-61.

27. Jiang $L$, Liang J, Jiang $M$, et al. Functional polymorphisms in the NBS1 gene and acute lymphoblastic leukemia susceptibility in a Chinese population. Eur J Haematol. 2011;86:199-205.

28. Berardinelli F, Masi A, Antoccia A. NBN gene polymorphisms and cancer susceptibility: a systemic review. Curr Genomics. 2013;14:425-40.

29. Miller S, Dykes D, Polesky H. A simple salting out procedure for extracting DNA from human nucleated cells. Nucleic Acids Res. 1988;16:1215.

30. Jabbour EJ, Faderl S, Kantarjian HM. Adult acute lymphoblastic leukemia. Mayo Clin Proc. 2005;80:1517-27.

31. Moradabadi A, Farsinejad A, Khansarinejad B, et al. Development of a high resolution melting analysis assay for rapid identification of JAK2 V617F missense mutation and its validation. Exp Hematol Oncol. 2019;8:1-7.

32. Moradabadi A, Fatemi A, Noroozi-Aghideh A. Analysis of the reannealinginstead of melting-curve in the detection of JAK2 V617F mutation by HRM method. J Blood Med. 2019;10:235.

33. Słomka M, Sobalska-Kwapis M, Wachulec M, Bartosz G, Strapagiel D. High resolution melting (HRM) for high-throughput genotyping-limitations and caveats in practical case studies. Int J Mol Sci. 2017. https://doi.org/ 10.3390/ijms18112316.

34. Batar B, Güven M, Bariş S, et al. DNA repair gene XPD, and XRCC1 polymorphisms and the risk of childhood acute lymphoblastic leukemia. Leuk Res. 2009;33:759-63.

35. Joseph T, Kusumakumary $P$, Chacko $P$, et al. DNA repair gene XRCC1 polymorphisms in childhood acute lymphoblastic leukemia. Cancer Lett. 2005;217:17-24.

36. Hu Z, Ma H, Chen F, et al. XRCC1 polymorphisms and cancer risk: a metaanalysis of 38 case-control studies. Cancer Epidemiol Biomarkers Prev. 2005;14:1810-8.

37. Wang Y, Sun Z, Xu Y. Carriage of NBN polymorphisms and acute leukemia risk. Int J Clin Exp Med. 2015;8:3769-76.
38. Mosor M, Ziółkowska I, Januszkiewicz-Lewandowska D, et al. Polymorphisms and haplotypes of the NBS1 gene in childhood acute leukaemia. Eur J Cancer. 2008;44:2226-32.

39. Smolkova B, Dusinska M, Hemminki K. NBN and XRCC3 genetic variants in childhood acute lymphoblastic leukemia. Cancer Epidemiol. 2014;38:563-8.

\section{Publisher's Note}

Springer Nature remains neutral with regard to jurisdictional claims in published maps and institutional affiliations.
Ready to submit your research? Choose BMC and benefit from:

- fast, convenient online submission

- thorough peer review by experienced researchers in your field

- rapid publication on acceptance

- support for research data, including large and complex data types

- gold Open Access which fosters wider collaboration and increased citations

- maximum visibility for your research: over 100M website views per year

At BMC, research is always in progress.

Learn more biomedcentral.com/submissions 